\title{
PRESENT STATUS OF ORGANIZATIONAL WORK-LIFE BALANCE PRACTICES IN BANGLADESH: EMPLOYEES EXPECTATION AND ORGANIZATIONAL ARRANGEMENTS
}

\author{
Md. Miraj Hossen \\ Huazhong University of Science and Technology, China \\ Mareum Begum \\ Huazhong University of Science and Technology, China \\ Chen Zhixia \\ Huazhong University of Science and Technology, China
}

\begin{abstract}
Work-Life Balance (WLB) or Work-Family Conflict (WFC) is one of the much talked issues in the modern business arena and all the stakeholder of business world such as- employers, employees, policy makers, academicians, consumers, and the common people are concerned about it. By considering the significances of the topic the researchers have taken an initiative to examine the present status of the WLB programs/ Employee friendly policies practices in the different organizations in Bangladesh through a designed questionnaire and interviewing the supervisors and employees of some selected organizations in multiple industries. Beside this the researchers also tries to explore what are the most wanted request comes from the employees, how the organizations respond against their requests, what perceptions bear the supervisor's and the employee's regarding WLB and what are the barriers may organization face to implement the WLB programs. The key findings of the research point out that most of the organizations in Bangladesh don't have any formal policy to make work-life balance but they follow some informal approaches (flexibility in time, location, \& schedule, leave provisions) to facilitates the employees WLB and make them relax, confident, committed and motivated towards their works to get satisfied employees and optimum HR productivity. The study concludes with mentioning some prospective outcomes of WLB which the organization may achieve by ensuring various WLB initiatives.
\end{abstract}

Keywords: Work-Life Balance (WLB), Work-Family Conflict (WFC), Flexible policy, HR productivity, Employee-friendly policies, Bangladesh.

DOI: http://dx.doi.org/10.15549/jeecar.v5i1.199

\section{INTRODUCTION}

Human resource is the most prominent assets and driving force of any organization and its proper utilization depends on the effective HR strategies and policies of the organizations. In order to facilitate optimum productivity through HR, it is very essential to manage the human capital effectively and effectively in a 
precise way (Deery \& Jago, 2015; Bohlander \& Snell, 2010; Mariappanadar, 2003; Moore, 2006). Beside this, every organization should focus on employees' work-life balance as both of these are two important domain of life. In the modern business world work-life balance is a buzzword and has great significance to the employees as well as employers in the wellstructured organizations (Beauregard \& Lesley, 2008; Eikhof, Warhurst, \& Haunschild, 2007). Nowadays, companies are gradually becoming aware of the significance of the concept of work-life balance and consider it as an important tool to attract and retain talents and facilitate sustainable human resources practices (Eikhof, Warhurst \& Haunschild, 2007; Stella, Paul \& Olubusayo, 2014). Conceptually, worklife balance (WLB) practices are the organizational arrangements to minimize workfamily conflict of employees and assist them to perform both family and work roles in effective manner (Lazar, Osoian \& Ratiu, 2010). The absence of such initiatives in organization will lead to work-family conflict (Becker \& Huselid, 1998) and make the employees anxious and emotionally shattered that in turn leads to reduced their productivity and increase more errors and inefficacy in both family and work life (Cappelli, 2000; Lingard et al., 2007; Wilkinson, 2008). Therefore, it is important for the employer's to ensure the balance between work life and career goals of their employees'. The mostly used method to increase the employees' commitment and productivity in the organization is to promoting flexibility (in terms of time-flexi, location flexi, leave and others) in the workplace (Wilkinson, 2008; Carlier, Llorente \& Grau 2012).

Oppositely, there are many issues act as barriers to make work-life balance in the organization like- organizational traditional cultures, unsupportive work environments, lack of supervisors' and peer supports, top management's attitudes and resistance, and lack of education, awareness, and communication about work life balance strategies (De Cieri et al., 2002; Wilkinson, 2008).

\section{Objectives of the Study}

Considering the literature on various initiatives available for facilitating work life balance as a foundation, the present study attempts to-

- Have an idea about the concept of Work-
Life Balance (WLB) and its related terms;

- Explore the present status of Work-Life Balance (WLB) practices in Bangladesh to mitigate employees Work-Family Conflict (WFC);

- Examines what type of supports employees ask to make work-life balance and how supervisors respond and barriers faced to meet their employee's needs;

- Have an idea about the potential outcomes and motivate the employers/ organizations to formulate a formal WLB policies to their organizations to achieve the outcomes.

The researchers focus on these sample industries because these are the most organized and specified sectors of the country and which has the most significance contributions to develop the economy and nation of the country.

\section{Methodology}

This is a descriptive and empirical study with an extensive literature survey and using primary data. For the study we collected data with a questionnaire survey and interviewing employees and supervisors/ administrators from 30 organizations covering 5 categories of industries operating in Bangladesh. The aim of the survey and interview was to collect data on the related issue of WLB practices in their organizations and asses their perception regarding the matter. In the survey questionnaire most of the respondents did not provide the biographical information as they are feeling job insecurity to express their organization's internal status. As it is a qualitative research, most of the questions of the questionnaire was open-ended and semistructured. The collected data were presented and analyzed mostly in qualitative way with minimum statistical tabulation. The sample included 30 HR managers/ Supervisors and 200 employees of the selected organizations.

The sample distributions are as follows: 
Table 1. Distribution of Samples.

\begin{tabular}{|c|c|c|c|c|}
\hline $\begin{array}{c}\text { Type of } \\
\text { Industry }\end{array}$ & $\begin{array}{c}\text { Type of } \\
\text { organization }\end{array}$ & $\begin{array}{c}\text { Sample of } \\
\text { Organization }\end{array}$ & $\begin{array}{c}\text { Respondents-HR managers/ } \\
\text { Supervisors/ Administrators }\end{array}$ & $\begin{array}{c}\text { Respondents- } \\
\text { Employees }\end{array}$ \\
\hline Education & Public & 2 & 2 & 22 \\
\cline { 2 - 5 } & Private & 3 & 3 & 18 \\
\hline \multirow{2}{*}{ Banking } & Public & 2 & 2 & 30 \\
\cline { 2 - 5 } & Private & 8 & 6 & 65 \\
\hline \multirow{2}{*}{ Telecom } & Public & 1 & 2 & 5 \\
\cline { 2 - 5 } & Private & 3 & 5 & 20 \\
\cline { 2 - 5 } & Public & 1 & 1 & 6 \\
\hline \multirow{2}{*}{ Others } & Private & 6 & 6 & 74 \\
\cline { 2 - 5 } & Public & 2 & 1 & 200 \\
\hline \multirow{2}{*}{ Total } & & 3 & 2 & 73 \\
\hline
\end{tabular}

\section{Research Questions}

The whole study is conducted by giving emphasizes on the following research questions:

- RQ1. What are the common requests come from the employees to facilitate WLB program?

- RQ2. How do the supervisors/ organizations respond to employees' request?

- RQ3. How do you assess the current status of WLB practices in your organization?

- RQ4. Do you think technology plays an important role to make WLB?

- RQ5. What factors act as the barriers to WLB initiatives?

\section{LITERATURE REVIEW}

\section{Conceptualization of Work-Life Balance (WLB)}

Making balance work and family life is central challenge for both employees and organizations perspectives (Valcour, 2007), and when an individual's life is balanced in this two domain it has been said that an individual's best interests are served (Kofodimos, 1993). Greenhaus and Allen (2011) defined work life balance as "the extent an individual's can perform his/ her duties in work and family domain effectively with minimum role conflicts. Work-life balance is defined as an employee's perception that multiple roles in both work and family domains of personal life and work life are performed in a responsible manner and satisfactory way (Clark, 2000; Ungerson \& Yeandle, 2005). The "worklife balance' is a broader concept that generally individuals struggle a lot to make a balance for all aspects of life such as personal care, child care, family care and work roles (Kirchmeyer, 2000). As life expectancy increases, present days the workers' responsibilities are increasing day by day like eldercare and childcare and it is badly needed to take some initiatives to make a balance between work and family life (Hammer \& Neal, 2008).

Work life balance (WLB) is the different ways of modifications in the working systems is to attain a well balanced between the work life and family life of employees (Lingard et al., 2007). This initiative helps employees to accommodate in both work and family domain that are very important for the personnel (De Cieri, 2002). All over the world, the primary objectives of work -life balance is to help the employees to achieve a self-motivated, and well-being that allows them to perform their multiple roles in an effective and efficient manner in the job place and at home (Moore, 2007). The organization and society as a whole 
should arrange the work-life balance strategically and accept as an organizational regular activities and work norms so that the employees and organizations can be benefited mutually (Moore, 2007). In the modern age, organizations are very much concerned about improving the human productivity and retaining the most efficient employees for long with them (Wilkinson, 2008) and for this reasons, most of the organizations are looking for the sustainable ways to make their employees life more flexible in the workplace so that organization can get optimum productivity with satisfied employees (De Cieri, 2005). According to Susi (2010) Work life balance is one of the drivers of employee satisfaction and modern organizations try to modify their organization's policies and cultures to retain the capable human capital, reduce work family conflict, employee stress, and increase job satisfaction and balanced in their lives. Considering this need, the organizations have been undergoing several changes in the organization structures like adopting less hierarchical and more participative structures (Wilkinson, 2008) From the extensive literature survey, it can be get an idea about various WLB initiatives like- flexible working arrangements, telecommuting, job sharing, leave provisions and childcare provisions [De Cieri, 2005). However, all these initiatives are not universal rather it varies from organizations to organizations considering its type of organization and the nature of specific jobs (De Cieri, 2002; Lingard et al., 2007).

Parkers and Langford (2008) recommend that organizations should concern about employees WLB conditions and formulate formal WLB policies with considering the employee's desires in their work and personal life. Organizations should give emphasize on employee-friendly policies to make the employees' daily activities easier and enjoyable and employees find themselves in lower level of stress and minimum work-life conflict situations (Frye \& Breaugh, 2004; Gajendran \& Harrison, 2007; Thompson et al., 1999).

Different provisions/ terms related to Work-Life Balance (WLB) Programs

To satisfy the needs of employees' work-life balance and make their life flexible different organizations have introduced different policies. As the organizations and nature of jobs are different from one another and same approaches' are not fit for all the organization; therefore, their strategies are different in nature. After reviewing different literatures, the popularly used techniques of making WLB can be listed in the following Table 1 .

Table 2. Summary of the popularly used WLB techniques.

\begin{tabular}{|l|l|}
\hline $\begin{array}{l}\text { Location and } \\
\text { Time flexi }\end{array}$ & $\begin{array}{l}\text { Location flexi can ensure WLB if the employees get opportunity to work near } \\
\text { branch office to their home or closer location. It can help them to easily reach } \\
\text { the job place with shortest period of time, in case of emergency they can go back } \\
\text { the home and again back to work. It can facilitate child care, elder care and other } \\
\text { also. } \\
\text { Time-flexi is the way an employee can fix his/her work day start or end time } \\
\text { with maintaining the minimum working hour fixed for a day. It is the most } \\
\text { popular, easiest, and widely practiced techniques to achieve organization targets } \\
\text { as well as making WLB (Lazar, Osoian \& Ratiu, 2010). }\end{array}$ \\
\hline $\begin{array}{l}\text { Day/Time-off- } \\
\text { in-lieu (TOIL) }\end{array}$ & $\begin{array}{l}\text { It means service on demand more or less as necessary. When the } \\
\text { organization/business has peak season and need more man hours then the } \\
\text { employees will work more and vice-versa. By the way the more hours will } \\
\text { compensate by providing day/time off in the recession time when manpower } \\
\text { requirements are relatively lower. Different literatures tell that employees } \\
\text { prefer time/day-off rather than receiving any other financial benefits or } \\
\text { monetary rewards (Moore, 2007; Bohlander \& Snell, 2010). }\end{array}$ \\
\hline
\end{tabular}


Table 2. Summary of the popularly used WLB techniques. (Continuous)

\begin{tabular}{|c|c|}
\hline Telecommuting & $\begin{array}{l}\text { In the advancement of technology, it is a great opportunity to work from } \\
\text { outside of the workplace (whether it is home or other place) through using } \\
\text { telecommunications. It helps organizations to enhance WLB and retain the } \\
\text { talent in the organizations (Bird, 2006; Jose, 2009; Holmes, 2010). Many } \\
\text { organizations welcome this technique and consider that it can reduce the costs } \\
\text { of office space and transport allowances (Horstman, 1999; Georgia, 2002; } \\
\text { Cremers, 2010; Nicolaisen, 2011). }\end{array}$ \\
\hline $\begin{array}{l}\text { Compressed } \\
\text { work week }\end{array}$ & $\begin{array}{l}\text { Compressed work week is the arrangements where employees are allowed to } \\
\text { work more hours per day or shifts and getting extra days-off or enjoying more } \\
\text { week-end days (Bohlander \& Snell, 2010). Lazar, Osoian \& Ratiu (2010) clarifies } \\
\text { this arrangement with an example, i.e., an employee can enjoy three days off } \\
\text { (weekend) by working four days and ten hours per day where he is supposed to } \\
\text { work forty-hours-in a week; or he can work an extra hour per day for two weeks } \\
\text { and enjoy additional one day off every two weeks or any combination by } \\
\text { fulfilling forty hours works in a week (McFarlane, 2009). }\end{array}$ \\
\hline Part-time work & $\begin{array}{l}\text { Part-time is a great opportunity for those who have outside business, family } \\
\text { responsibilities, even though who have disabilities and health problems. In this } \\
\text { arrangements, people can work part-time basis less than forty hours a week } \\
\text { with considering their own personal affairs (Chick, 2004; Asadullah, 2008). This } \\
\text { technique can help to minimizes gender inequality as the mothers can work and } \\
\text { gain job experience besides playing their family roles (Lazar, Osoian \& Ratiu, } \\
\text { 2010; Doellgast, Nohara \& Tchobanian, 2009). }\end{array}$ \\
\hline Job-sharing & $\begin{array}{l}\text { Job sharing is the process where two or more employees voluntarily share a } \\
\text { given full-time job and also share the remuneration among themselves } \\
\text { proportionately as per the organizational agreement. This is an opportunity to } \\
\text { use additional manpower during busy and peak business periods (Lazar, Osoian } \\
\text { \& Ratiu, 2010). Doellgast, Nohara \& Tchobanian (2009) argued that job sharing } \\
\text { can help to retain human talent, increase productivity through combining a } \\
\text { multiple talent, and experience in a single job. }\end{array}$ \\
\hline $\begin{array}{l}\text { Annualized } \\
\text { hours }\end{array}$ & $\begin{array}{l}\text { In this method, employees are able to choose their preferred hours and days of } \\
\text { work within a certain time boundary and the working time is calculated annual } \\
\text { basis considering the time boundary (Puigarnau \& Ommeren, 2010). In this } \\
\text { arrangement, employees can get chance to fix their annual hours considering } \\
\text { work hours, shifts, days, weeks, and months according to their availability } \\
\text { through which the can be able to make WLB in a possible manner (Hyman \& } \\
\text { Summers, 2007). }\end{array}$ \\
\hline $\begin{array}{l}\text { Child-care } \\
\text { provisions }\end{array}$ & $\begin{array}{l}\text { Child-care arrangements is one of the most important techniques to get the } \\
\text { most possible output from the working mothers. It can be fully or partially } \\
\text { employer subsidized program which helps to improve employees' morale, } \\
\text { efficiency, commitment, and overall productivity. (Darcy \& McCarthy, 2007; } \\
\text { Edwards, 1979; Friedman, 1989). Different literatures show that such type of } \\
\text { initiatives lead to the positive organizational culture, employee satisfaction, and } \\
\text { employee retention. (Kossek, Dass \& DeMarr, 1994; Eikhof, Warhurst, } \\
\text { Haunschild, 2007; Cowling, 2005). }\end{array}$ \\
\hline
\end{tabular}


Table 2. Summary of the popularly used WLB techniques. (Continuous)

\begin{tabular}{|c|c|}
\hline $\begin{array}{l}\text { Leave } \\
\text { provisions }\end{array}$ & $\begin{array}{l}\text { This provision is practiced each and every organization all over the world but } \\
\text { in different ways as per the countries own labor act. It considers the different } \\
\text { types of leaves such as fully paid, partially paid and unpaid (such as leisure, } \\
\text { childcare, medical care, educational, etc.) provided to employees by considering } \\
\text { theirs needs and valid grounds. (Eikhof, Warhurst, Haunschild, 2007; Wayne \& } \\
\text { Cordeiro, 2003). According to Human Rights Watch (2007), a well-defined leave } \\
\text { policy helps employees to have sufficient time to maintain work and family } \\
\text { affairs in a positive way with good WLB. Studies show that such type of leaves } \\
\text { can lead to employee satisfaction, motivation, and better personal and family } \\
\text { well-being (Khallash \& Kruse, 2012; Friedman, 1989; Kossek, Dass \& DeMarr, } \\
\text { 1994). }\end{array}$ \\
\hline $\begin{array}{l}\text { Supervisory } \\
\text { support }\end{array}$ & $\begin{array}{l}\text { Supervisors' can play direct role to help employees work-life balance as they } \\
\text { are the direct reporting bosses of their subordinates. Different literature has } \\
\text { mentioned the role of supervisory support to facilitate the WLB. Supportive } \\
\text { supervisors take initiatives and make organizational environment friendly } \\
\text { which can help to make employees life balance in both work and family domain } \\
\text { (Thomas \& Ganster, 1995). The major role player of the employees WLB process } \\
\text { is their supervisors or reporting bosses' (e.g., Allen, 2001; Thomas \& Ganster, } \\
\text { 1995). The employees expect both emotional and instrumental support to make } \\
\text { their work-life balance and the employee friendly supervisors should consider } \\
\text { both of the points. (Perrewe, Treadway, \& Hall, 2003). Employees expect some } \\
\text { sympathetic and mental caring as "emotional support" whereas expecting } \\
\text { proper resources and equipment to carry the daily activities smoothly } \\
\text { "instrumental support" (Rooney \& Gottlieb, 2007). }\end{array}$ \\
\hline
\end{tabular}

FINDINGS AND ANALYSIS/ DISCUSSIONS

Major Findings related to the research questions:

Bangladesh is a labor intensive country with a remarkable level of educated unemployed people. So, the employers or organizations have lots of labor options which makes them careless about the greater interest of the employees. Most of the organizations are profit oriented and treated people as a machine rather as a human being. Moreover, following tables can give a clear idea about overall WLB practices by the Bangladeshi organizations.

Table 3. Employee's requests to facilitate WLB programs.

\begin{tabular}{|c|c|c|c|}
\hline \multicolumn{4}{|c|}{ RQ1. What are the common requests come from the employees to facilitate WLB program? } \\
\hline & WLB provisions Requested by the employees & Response & $\%$ \\
\hline i. & $\begin{array}{l}\text { Time-flexi (working targeted hours with flexible starting and } \\
\text { ending) }\end{array}$ & 183 & $91.5 \%$ \\
\hline ii. & Location-flexi (get transfer or posting the nearest place to home) & 178 & $89.0 \%$ \\
\hline iii. & $\begin{array}{l}\text { Part-time work (when it is necessary to concentrate more to } \\
\text { family) }\end{array}$ & 64 & $32.0 \%$ \\
\hline iv. & Compressed work week (more or less work days in case) & 112 & $56.0 \%$ \\
\hline v. & Telecommuting (but not on call during weekends and holidays) & 102 & $51.0 \%$ \\
\hline vi. & Remove work-load and stress in the job (job sharing) & 115 & $57.5 \%$ \\
\hline vii. & Child-care provision (onsite and organization's subsidized) & 162 & $81 \%$ \\
\hline
\end{tabular}


Table 3. Employee's requests to facilitate WLB programs. (Continuous)

\begin{tabular}{|r|c|l|l|}
\hline viii. & $\begin{array}{c}\text { Leave (maternity/paternity, medical/sick, higher studies, } \\
\text { recreation) }\end{array}$ & 156 & $78 \%$ \\
\hline ix. & Work resources (staff, training, ICT support, other equipment) & 109 & 54.5 \\
\hline $\mathrm{x}$. & Job security (in case of private organizations especially) & 79 & $39.5 \%$ \\
\hline $\mathrm{xi}$. & Onsite amenities (Canteen, bank, post office, pre-schooling) & 48 & $24 \%$ \\
\hline xii. & Compensations (Requesting extra, rises, or some form of pay) & 33 & $16.5 \%$ \\
\hline xiii. & Allowing to change schedule (in work days or even weekend) & 39 & 19.5 \\
\hline xiv. & Official vehicle for travel to avoid trafficking on the way & 118 & $59.5 \%$ \\
\hline xv. & $\begin{array}{l}\text { Emotional supports ( family affairs and job affairs- projects and } \\
\text { team) }\end{array}$ & 117 & $58.5 \%$ \\
\hline xvi. & $\begin{array}{c}\text { Lower hierarchy (direct communication to the supervisor/ top } \\
\text { Mgt.) }\end{array}$ & 56 & $28 \%$ \\
\hline
\end{tabular}

From the table it is to be said, the interviewed employees of the selected organizations mostly face problem with their work time (91.5\%), location $(89 \%)$ and child care $(81 \%)$ to make their work-life balance and they asked to their supervisors to give some flexibility regarding this issues. Beside the, they emphasized on official vehicle (59.5\%), paid leave for their valid ground (78\%), and ask for emotional support (58.5\%) for their crisis moment.

Table 4. Organizational arrangements to facilitate WLB programs.

RQ2. How do the supervisors/ organizations respond to employees' request?

\begin{tabular}{|l|l|}
\hline $\begin{array}{l}\text { Flexi-time } \\
\text { Schedule }\end{array}$ & $\begin{array}{l}\text { In Bangladesh, most of the organization whether public or private follow a } \\
\text { non-flexible working hour with at least 8-hours work per day. Beside this, a } \\
\text { few companies (education sector especially university teaching, health sector- } \\
\text { doctors, and some government offices) practiced time-flexi to help their } \\
\text { employees' WLB. This time-flexi differ from organization to organization } \\
\text { depending on the nature of job and business, organizational requirements, } \\
\text { culture and practices. Employees has different opinions regarding time-flexi } \\
\text { practiced by organization- some employees find it has not any benefits as they } \\
\text { are to work the same hours of work per day. Oppositely, some other finds huge } \\
\text { significance of time-flexi as it helps to avoid peak-hour traffic jams, taking care } \\
\text { of child and elder rotationally (when spouse is employed), sending and } \\
\text { bringing child to school, managing domestic works etc. Moreover, it was found } \\
\text { that flexi time is helpful to make a balance in both the work and family life in } \\
\text { work days. Other hand, some HR practitioners and supervisors argued that } \\
\text { "flexible-time schedule act as an obstacle to fix the meeting time and arranging } \\
\text { schedule for different employees in differently but to some extent it works well } \\
\text { and it totally depends on the job category." }\end{array}$ \\
\hline
\end{tabular}


Table 4. Organizational arrangements to facilitate WLB programs. (Continuous)

\begin{tabular}{|c|c|}
\hline $\begin{array}{l}\text { Time-off-in-lieu } \\
\text { of extra work } \\
\text { hours }\end{array}$ & $\begin{array}{l}\text { It is commonly experienced all over the world and also in Bangladesh. It } \\
\text { depends on the organizational culture, nature and position of job. When } \\
\text { employees work more than the specified hours then it is considered as } \\
\text { overtime for the lower levels position or non-supervisory positions and they } \\
\text { are paid for their extra hour works. Naturally some employees who hold higher } \\
\text { positions (supervisory positions) need to stay longer time after assigned work } \\
\text { hours but they are not entitled to overtime pay rather the organizations offer } \\
\text { them time-off-in lie mandatorily when the organization has off-peak business } \\
\text { hour. Nowadays, many organizations and employees consider it as a great } \\
\text { initiatives of work- life balance practices. }\end{array}$ \\
\hline Telecommuting & $\begin{array}{l}\text { Though Bangladesh is not so advance in the ICT but a great number of people } \\
\text { are under the coverage of the telecommunication. But the telecommuting is } \\
\text { not so much popular to use as a technique for WLB. Studies shows that a few } \\
\text { companies formally allowed some of their key employees to work from home } \\
\text { or out of workplace by using telecommuting under certain conditions (sickness } \\
\text { of the employees, females who are on maternity leave, emergency engagement } \\
\text { in personal life- elder care, child care) with the prior consent of their } \\
\text { supervisor(s) for a certain period (specific days). Employees who availed this } \\
\text { WLB option they must work as if they were working in office by using team } \\
\text { viewer they can access official files, share their files, sending and receiving e- } \\
\text { mails, responding telephone calls etc. }\end{array}$ \\
\hline Part-time work & $\begin{array}{l}\text { This is a well-practiced technique in many organizations which create some } \\
\text { job opportunity for the students and jobless educated person. Especially this } \\
\text { type of job includes telecom call center, data entry, research filed survey etc. } \\
\text { Beside this, some experts' professions- physicians, educationist, journalists, IT } \\
\text { specialists take this opportunity as a free-lancer. This work limit the working } \\
\text { time up to } 40 \text {-hours a week and mostly contractual in nature. From the } \\
\text { organizational perspectives it helps to save labor costs and improve flexibility } \\
\text { for both employees and employers. }\end{array}$ \\
\hline Job sharing & $\begin{array}{l}\text { Job sharing is practiced and welcome in Bangladesh in some specific job } \\
\text { categories such as education (teachers) and health sector (doctors and nurses), } \\
\text { judiciary and some other consultancy and construction sector. Actually it } \\
\text { depends on the countries labor laws, organizational policies and cultures and } \\
\text { the nature \& type of job. }\end{array}$ \\
\hline $\begin{array}{l}\text { Compressed } \\
\text { working hours }\end{array}$ & $\begin{array}{l}\text { This provision is not found in the practices in Bangladesh at all as the } \\
\text { employers and employees think it is difficult to adjust longer work-hours, longer } \\
\text { work-days and greater leisure period as there is no extra organizational } \\
\text { arrangements for this like- staff and resource support, organizational security } \\
\text { problems and so on. In any special cases, informally a very few organizations } \\
\text { hardly practice but it is not mentionable. In the study we have found, } \\
\text { "sometimes this type of practice is frustrating to employees if the authority asks } \\
\text { them to come earlier or leave later." }\end{array}$ \\
\hline
\end{tabular}


Table 4. Organizational arrangements to facilitate WLB programs. (Continuous)

\begin{tabular}{|c|c|}
\hline $\begin{array}{l}\text { Different } \\
\text { Leaves }\end{array}$ & $\begin{array}{l}\text { Different types of paid as well as unpaid leave provisions are allowed in } \\
\text { Bangladesh as per the labor laws of the country. The most common forms of } \\
\text { leaves are as- Annul casual leave, recreation leave, study leave (higher } \\
\text { education), mandatory maternity leave, paternity leave (rare and small in } \\
\text { practice), medical/sick leave, compassionate leave (informal but practiced in } \\
\text { case of emergency or great loss), and Hajj pilgrimage leave (for the Muslim } \\
\text { devotes). All this leaves are allowed with paid in the government (public sector) } \\
\text { where as it is practiced as per the labor law and organizational leave policy for } \\
\text { the private organizations. This supports initiatives help the employees to attend } \\
\text { their family and social matters, and contribute to the achievement of WLB. }\end{array}$ \\
\hline $\begin{array}{l}\text { Child-care and } \\
\text { Pre-schooling }\end{array}$ & $\begin{array}{l}\text { Child bearing and caring is the most challenging job for the working mothers } \\
\text { and it creates a great problem if organization has no family supportive policies. } \\
\text { Though at present in Bangladesh, most of the organizations has no child-care } \\
\text { and pre-schooling facilities but all the organizations are much more concerned } \\
\text { about the matter. Especially the government organizations are conscious to } \\
\text { arrange child-care and pre-schooling provisions for the child of working mother } \\
\text { in their office premises. Beside this, some private, and autonomous } \\
\text { organizations are offering such type of facilities to make the female worker's life } \\
\text { balance. }\end{array}$ \\
\hline $\begin{array}{l}\text { Informal } \\
\text { supervisory } \\
\text { support }\end{array}$ & $\begin{array}{l}\text { As most of the organizations has no formal practices or policies regarding WLB } \\
\text { arrangements, sometimes the line managers or supervisors do favor to their } \\
\text { employees without any formal documented policy. The supervisor may allow } \\
\text { some time-flexi, day-off, telecommuting or such type of favor in some urgent/ } \\
\text { special cases. Following two statements can give a clear message about this } \\
\text { practices- "Though we don't practice any formal WLB policy in our organization } \\
\text { but our different department informally allows it (time-flexi, day-off, } \\
\text { telecommuting, emotional and instrumental support, ensuring friendly work- } \\
\text { environment and peer relations, resource support, arranging recreational } \\
\text { programs and so on) in some cases within the power limit of the authority." } \\
\text { another quotes, "we hardly practice WLB programs (early come and early } \\
\text { leave)in very informal way by considering the humanitarian ground of the } \\
\text { candidates especially for the female employees (in pregnancy case or child } \\
\text { caring issues or taking elder care), and those who are currently attending their } \\
\text { higher studies (especially in their exam days or urgent class day)." }\end{array}$ \\
\hline
\end{tabular}

Table 5. Employee's opinions regarding WLB practices.

RQ3. How do you assess the current status of WLB practices in your organization?

As there is a growing number of dual career couples and women participation in the global workforce and it is really tough to perfectly manage two domains (work-family) of life. Almost all the organizations in Bangladesh are now facing it is a great challenge to get optimum productivity through their employees especially from women employees and the dual-career couples. By considering this reality, nowadays every organization are realizing the need for formal or informal WLB programs and some of the organizations has appointed HR specialists who can develop the employer-employee friendly WLB programs with securing the interest of both parties. The evaluation of the present status of WLB practices in Bangladeshi organization can be pointed out with the following quotations of the respondents- 
Table 5. Employee's opinions regarding WLB practices. (Continuous)

As there is a growing number of dual career couples and women participation in the global workforce and it is really tough to perfectly manage two domains (work-family) of life. Almost all the organizations in Bangladesh are now facing it is a great challenge to get optimum productivity through their employees especially from women employees and the dual-career couples. By considering this reality, nowadays every organization are realizing the need for formal or informal WLB programs and some of the organizations has appointed HR specialists who can develop the employer-employee friendly WLB programs with securing the interest of both parties. The evaluation of the present status of WLB practices in Bangladeshi organization can be pointed out with the following quotations of the respondents-

Some respondents (managers/ supervisors) argued that, "In Bangladesh WLB initiatives are changing steadily as it needs long-term strategic plan for altering the present conditions. It won't be wise to make hurry to introduce any new plan because people are always reluctant to welcome any kind of change. Moreover, it may create conflicting situation with organizational existing policies and objectives." Another manger's statement also gives the proof of the previous statement, "In some cases, if any special schedule like time-flexi or extra ordinary leaves offer to the employees they feel reluctant to avail this they become worried and think like that- the financial condition of the organization may be unhealthy, organization may be preparing for job cut and we may be going to lose our jobs."

Oppositely, the study found evidences that the WLB practices is still in the inception stage and most of the supervisors/ mangers/ organizations are not welcome or even aware about this concept. The supportive arguments (employee's) behind the previous statement are: "it is the general concepts of the most managers, organization has a specified policies and employees are aware about this traditional practices. Employees who are working this organization they come with a mindset of doing job by following the current practices and the organization should not welcome their personal problems or to introduce any informal favor or WLB programs." Another employees argues like that "Our WLB provisions used as an ornaments and applied only for some key officials and high performers and the main motive is to do this favor only for the retention of these key persons." Some employees claim that, "they are struggling much to maintain WLB as they are overloaded in the organizations and for this reason when they are in home (or even in holidays, weekends) also thinking about incomplete works and go back to works. Sometimes, this indicates their low performance and they are worrying about losing jobs also."

Table 6. Role of technology to facilitate WLB.

RQ4. Do you think technology plays an important role to make WLB?

Though the technological advancement is going faster day by day and reaping the benefits of the technology all over the world. But in case of Bangladesh we are lag behind to take this benefits as our infrastructure is not enough supportive to this. Though some employees ask for telecommuting as a tool to WLB but most of the respondents also mentioned that "technology also act as one of the barriers to the employees' WLB process. They argued that technology control employees $24 \mathrm{~h} / 7 \mathrm{~d}$ which is very much agonizing and resulting to stressed mental condition unhappy conjugal and family lives, or even create some psychological and health problems." Sometimes employees do not get any personal time even at home as they carry office works with them and thinking about the progress of their works all the day-night as they are connected with technology like- receiving office calls and checking e-mails and giving response of these. So, it is to say technology has made life more dynamic and challenging as well to make the balance in their work-life. 
Table 7. Obstacles to ensure WLB programs.

\section{RQ5. What factors act as the barriers to WLB initiatives?}

Though Bangladesh is a small country but we have huge workable educated people and these people come from different region and culture. So it is little bit tough for the organization to manage this people as they have diverse anticipations and predilections. Beside this, majority of the employees are not aware about the significance of WLB for sustainable productivity and longterm employee well-being and they try to do their best to secure their job as there is job insecurity and unemployment problems is common in Bangladesh. These things naturally act as the barriers to introduce the WLB programs as the employers take this as opportunities to use the employees' fullest talent without giving any more extra facilities. Moreover, the study has found the following obstacles (by interviewing the manager/ employees) to formalize the WLB facilities-

$\checkmark$ Implement WLB program is out of supervisor's authority;

$\checkmark$ It is the job requirement- as specified in the organization's policy;

$\checkmark$ Multiple involvement of works- as organization wants to reduce HR costs;

$\checkmark$ Hard to break the long-term practiced tradition or culture of the organization;

$\checkmark$ Insufficient resources such as - Human resources, tools and equipment etc.;

$\checkmark$ Time constraints- need time to make change and introduce new policy.

\section{DISCUSSION/ ANALYSIS OF THE MAJOR FINDINGS}

The major finding of the present status of WLB practices can be highlighted in the following analysis/discussions:

- It is to be said day by day the organizations are realizing the need of WLB and strategically introduced some initiatives formally or informally in their organizations.

- Though most of the employees in the developing or least developed countries prefer monetary rewards than such type of flexibility but it is also proved in this study that they are getting motivation and willing to taking benefits of WLB initiatives of their organizations.

- AS most of the employees in the surveyed organization are feeling that the job is badly needed for their lives. So, they have to survive in the job for their career by considering the family or social lives even they were married or single, whether they have children or not; they give priority to their job and career for their survival.

- It is challenging for the organizations to measure accurately the gross benefits of the outcomes of the WLB initiatives in their organization as it works differently with different employee's perceptions and personalities.
- The successful application of the WLB initiatives is depends on some variables such as- cultural and legal issues of the country, organizational strategic plan, nature of the business and job, employee's attitudes and perceptions, and also the demographic profiles of the employees.

- Though some of the selected organizations formally or informally tries to practices the WLB programs but they are lag behind to ensure the equity and fair treatments for all (as most of the respondents pointed out WLB is practiced only for the top levels and high-performers).

- The study found that WLB practices is not beneficiary all over; it also has some negative outcomes also which can be listed out as- create problem to fixed meeting time for flexible hours, stress and autonomy comes due to irregular working hours, lack of common leisure time/ weekend to attend social gatherings and so on.

- Though most of the surveyed organizations have not WLB programs in black and white format but it is noticeable that the demands and approval of WLB programs increasing day by day and the respondents spontaneously acknowledge they are performing (reporting supervisors of the departments/ units allowing) some WLB initiatives in 
informal ways considering the humanitarian ground of the employees.

- The practices of WLB programs differ from one organizations to another due to the nature of job and industry and it evidence from the study- paid study leave, paid religious (hajj pilgrims or other devotees) leave, paid maternity leave, and paid medical leave, and extra paid recreation leave, flexible work-schedule and working hours, location-flexi are mostly practices in the publics sector organizations whereas part-time/ contractual job, job rotation, job sharing, different shifts (choose one flexible shifts), paternity leave, time-flexi/ flexible working hours, compressed working hours are more practiced in the private organizations.

- The attitudes of the supervisors and top managements sometimes acts as a barrier to get the benefits of WLB informally as they are target and profit oriented and they feel if they allow any demand of the employees, they will make is as a regular practices and the organizations will be face future crisis.

\section{EXPECTED OUTCOMES OF WLB PROGRAMS}

WLB has a great significance and implication in both individual life and organizational prosperity. Different literature displays the proofs that there is a positive relationship between WLB programs and employee commitment, motivation, engagement, productivity, job satisfaction (Gottlieg, Kelloway
\& Barham, 1998; Lazar, Osoian \& Ratiu, 2010). Thompson et al. (1999) have found that the availability of WLB programs can enlarged the emotional attachment, organizational commitment and loyalty which can also dwindled the employee turnover intentions. Organizations WLB programs helps to retain the high performing employees (Lester, 2013) and minimizes absenteeism (Landauer, 1997). Obviously, less absenteeism indicates the better health conditions of the employees and in longrun it helps to reduce the organizational health insurance cost and medical treatment expenses of the employees as well (Lockwood, 2003). WLB is positively related with employee satisfaction (work-family life), employee productivity, and sense of belonging (Baltes, Briggs, Huff, Wright, \& Neuman, 1999; Kossek \& Ozeki, 1998). Allen et al., (2000) addressed the negative impact when the organization has no work-life balance- life dissatisfaction, hypertension, over stress, turnover intention, and frustration- depression. Though many research shows that there is a positive association between WLB programs and employee life satisfaction, engagement, commitment, performance and productivity, and many more but WLB initiatives are not the single factor rather it is one of the important factors behind these outcomes (Hyman \& Summers, 2007; Holmes, 2007; Holmes, 2010) However, it is suggested that the little practice of WLB programs cannot ensure the optimum level of satisfaction and reduce work-life conflict. (Thompson et al., 1999).

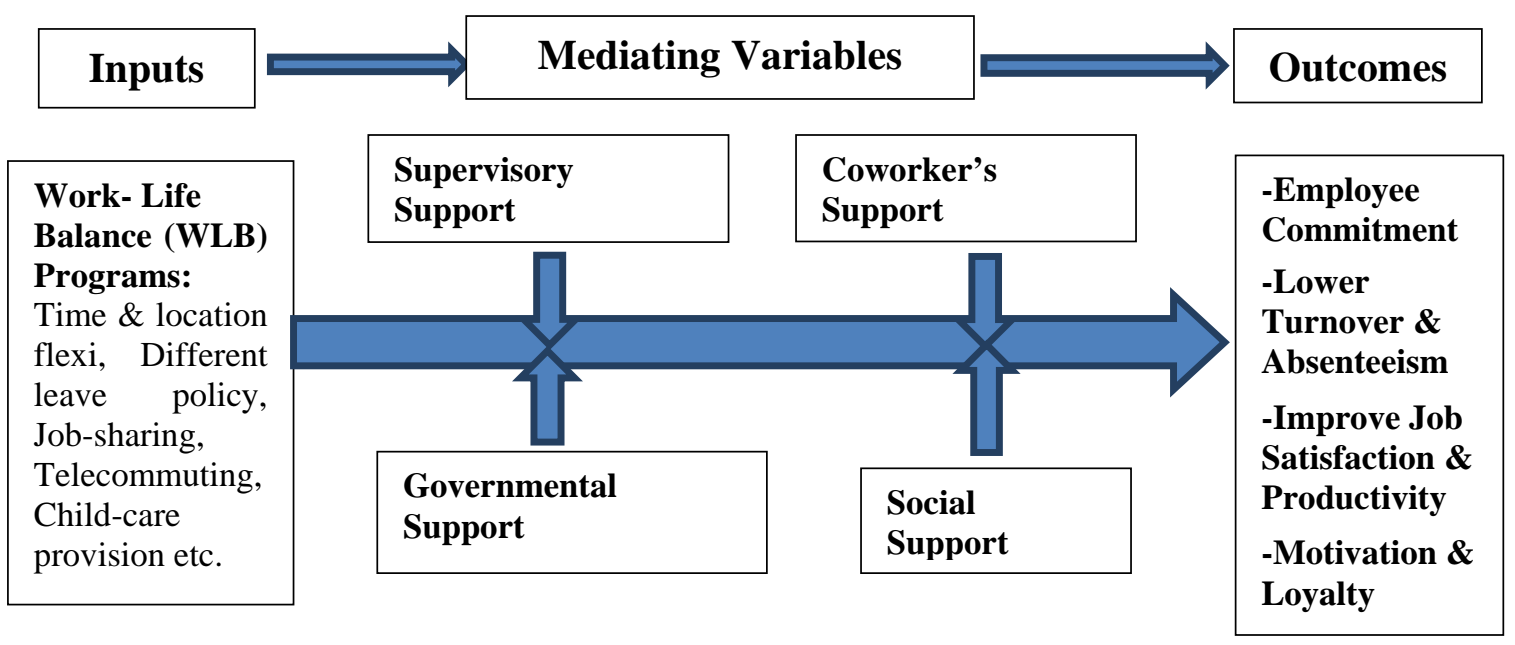

Figure 1. Proposed Model for the Outcomes of Organizational WLB Policy. 
Although there are many literatures enunciates the affirmative impact of WLB programs on both individual (employees) and organizations (employers) but it is tough to measuring the outcomes accurately. By the way organization may face challenge to quantity the benefits of different WLB initiatives and their relative paybacks (Eby et al., 2005; Lazar, Osoian \& Ratiu, 2010). In order to get the optimum output through WLB programs first of all the organizational policies and culture should be changed and formulate employee-friendly policies instead. Beside this, employees should be aware about their rights, responsibilities and capable to apprehend the importance of WLB programs and the effects of this programs to sustainably perform their duties in the workplace and outside.

\section{RESEARCH LIMITATIONS AND FUTURE RESEARCH AGENDA}

The present study was conducted considering only 5 categories of industries with special focused on 30 organizations in Bangladesh which makes it faulty to make a general comment about the overall scenario of the WLB practices of the country. However, the selection of organizations and respondents are done as per the convenient to the researchers as the researchers has not receive any fund from any of the sources to conduct this research and this may be not well justified sampling process. Another limitation is data collection as most of the supervisors and employees feel reluctant to express their real practices of WLB as they are anxious about their job security. Though the study may have some limitations related to sample selection, optimum level of data accuracy, or coverage of small area or industries but the researchers consider this study as a foundation for the further studies on the topic. This qualitative research can act as the groundwork to assist in theory building as considered by Casper et al. (2007). The researchers also have intended to do further advance studies about this if the fund and time is available to them. The directions for the future researchers, it can be done more precise way with an extensive survey and quantitative analysis by considering more industries or any single industry with a large number of sample, cross industries studies, cross countries analysis or even measuring the outcomes of WLB practices in different industries of over the countries.

\section{CONCLUSION}

Conflicts in every aspect of life is normal whether it is work-life or personal life and we the people should try to mitigate it through making balance and adjust with the prevailing situations. This qualitative research tries to identifies the present status of WLB practices and way out the prospective solutions of worklife conflict which can help to make employees work-life balance in both domains. The study give emphasis on three dimensional issues likewhat is the present practices, what do the employees request and what initiatives the supervisors taken to balancing work-life. Beside these, the researchers try to find out the employees and their supervisors perceptions and satisfaction about the present conditions of WLB practices in Bangladesh. Though most of the organizations has no formal WLB policies but the research indicates majority of the surveyed organization practices it in informal ways and the public sector organizations are ahead of it. To sum up, the study recommended that the organizations should come forward with a formal WLB polices and implement the policy to achieve the sustainable competitive advantages and optimum productivity through the working peoples. Though it is not a matter of single day and it may face a number of steps but both employees and employers should be aware and take necessary steps in this regards.

\section{REFERENCES}

Allen, T. D. (2001). Family-supportive work environments: The role of organizational perceptions. Journal of Vocational Behavior, $58,414-435$.

Allen, T. D., Herst, D. E. L., Bruck, C. S., \& Sutton, M. (2000). Consequences associated with work-to-family conflict: A review and agenda for future research. Journal of Occupational Health Psychology, 5, 278308.

Asadullah M, Fernández R. Work-life balance practices and the gender gap in job satisfaction in the UK: evidence from matched employer-employee data. IZA DP no. 3582; 2008.

Baltes, B. B., Briggs, T. E., Huff, J. W., Wright, J. A., \& Neuman, G. A. (1999). Flexible and compressed workweek schedules: A metaanalysis of their effects on work-related 
criteria. Journal of Applied Psychology, 84, 496-513.

Beauregard A, Lesley CH. Making the link between work-life balance practices and organizational performance. Hum Resour Manag Rev 2008; 19:1.

Becker B, Huselid M. High performance work systems and firm performance: a synthesis of reserch and managerial implications. ResPers Hum Resour Manag 1998; 16:53101.

Bird J. Work-life balance doing it right and avoiding the pitfalls, vol. 33. Wiley Periodicals; 2006.

Bohlander GW, Snell S. Managing human resources. Mason $(\mathrm{OH})$ : South Western Cengage Learning; 2010.

Cappelli P. A market driven approach to retaining talent. Harv Bus Rev 2000;78(1):103-11.

Carlier Sandra Idrovo, Llorente Consuelo Leon, Grau Marc Grau. Comparing work-life balance in Spanish and Latin-American countries. Eur J Train Dev 2012;36(23):286-307.

Casper, W. J., Eby, L. T., Bordeaux, C., Lockwood, A., \& Lambert, D. (2007). A review of research methods in $\mathrm{IO} / \mathrm{OB}$ work-family research. Journal of Applied Psychology, 92, 28-43.

Chick ED. Fundamentals of work-life balance. New York: American Society for Training and Development; 2004.

Clark SC (2000). Work/Family Border Theory: A New Theory of Work/Family Balance. Human Relations 53(6): 747-770.

Cowling M. Still at work? London: Work Foundation; 2005.

Cremers J. Rules on working conditions in Europe: subordinated to freedom of services? Eur J Ind Relat 2010;16(3):293306.

Darcy C, McCarthy A. Work family conflict: an exploration of the differential effects of a dependent child's age on working parents. J Eur Ind Train 2007;31 (7).

De Cieri H, Holmes B, Abbott J, Pettit T. Achievements and challenges for work/ life balance strategies in Australian organizations. Int J Hum Resour Manag 2005;16(1):90-103

De Cieri H, Holmes B, Abbott J, Pettit T. Work- life balance strategies: progress and problems in Australian organizations. Working paper 58/02. Monash University, Victoria; 2002.

Deery M, Jago L. Revisiting talent management, work-life balance and retention strategies. Int J Contemp Hosp Manag 2015;27(3):45372.

Doellgast V, Nohara H, Tchobanian R. Institutional change and the restructuring of service work in the French and German telecommunications industries. Eur J Ind Relat 2009;15(4):373-94.

Eby LT, Casper WJ, Lockwood A, Bordeaux C, Brinely A. Work and family research. Content analysis and review of the literature. J Vocat Behav 2005; 66:124-39.

Edwards R. Contested terrain. New York: Free Press; 1979.

Eikhof DR, Warhurst C, Haunschild A. Introduction: What work? What life? What balance? Critical reflections on the worklife balance debate Empl Relat 2007;29(4):325-33.

Friedman E. Impact of childcare on the bottom line. In Investing in people: a strategy to address America's workforce crisis. Washington, D.C.: Commission on Workforce Quality and Labor Market Efficiency, U.S. Department of Labor; 1989. p. 1427-75.

Frye, K. N., \& Breaugh, J. A. (2004). Familyfriendly policies, supervisor support, workfamily conflict, family-work conflict, and satisfaction: A test of a conceptual model. Journal of Business and Psychology, 19, 197220.

Gajendran, R.S., \& Harrison, D.A. (2007). The good, the bad, and the unknown about telecommuting: A meta-analysis of the psychological mediators and individual consequences. Journal of Applied Psychology, 92, 1524-1541.

Georgia P. Work-life balance: a case of social responsibility or competitive advantage? 2002. Retrieved from 〈http://www.worklifebalance.com/assets/ pdfs/casestudy.pdf).

Gottlieg BH, Kelloway EK, Barham E. Flexible work arrangements: managing the workfamily boundary. New York: John Wiley \& Sons; 1998. 
Greenhaus, J., \& Allen, T. (2011). Work-family balance: A review and extension of the literature. In J. C. Quick and L. E. Tetrick (Eds.), Handbook of occupational health psychology (2nd edition). Washington, DC: American Psychological Association.

Hammer, L. B., \& Neal, M. B. (2008). Working sandwiched-generation caregivers: Prevalence, characteristics, and outcomes. The Psychologist-Manager Journal, 11, 93112.

Holmes B. National flexible work-a pulse survey. CCH Australia in Conjunction with Managing Work Life Balance International; 2010.

Holmes B. National work/life benchmarking study. CCH Australia in Conjunction with Managing Work-Life Balance International; 2007.

Horstman B. Decentralized and deregulated Australian industrial relations: the effects on HRM and IR in small enterprises. Empl Relat 1999;21(3):325-41.

Human Rights Watch. The UAE's draft labor law. Human rights watch's comments and recommendations. March 2007, No. 1; 2007.

Hyman J, Summers J. Work and life: Can employee representation influence balance? Empl Relat 2007;29(4):367-84.

Jose S. Cisco study finds telecommuting significantly increases employee productivity, work-life flexibility and job satisfaction; 2009.

Retrieved from 〈http://newsroom.cisco.com/dlls/2009/prod _062609.html>.

Khallash S, Kruse M. The future of work and work-life balance 2025. Futures 2012; 44:678-86.

Kirchmeyer, C. (2000). Work-life initiatives: Greed or benevolence regarding workers' time? In C. L. Cooper \& D. M. Rousseau (Eds.), Trends in organizational behavior: Time in organizational behavior (Vol. 7, pp. 79-93). Chichester, England: Wiley.

Kofodimos, J.R. (1993), Balancing Act, San Francisco, CA: Jossey-Bass.

Kossek E, Dass P, DeMarr B. The dominant logic of employer-sponsored work and family initiatives: human resource managers' institutional role. Hum Relat 1994;47(9).

Kossek, E. E., \& Ozeki, C. (1998). Work-family conflict, policies, and the job-life satisfaction relationship: A review and directions for organizational behavior-human resources research. Journal of Applied Psychology, 83, 139-149

Landauer J. Bottom-line benefits of work/life programs. HR Focus 1997;74 (7):3-4.

Lazar I, Osoian C, Ratiu P. The role of work-life balance practices in order to improve organizational performance. Eur Res Stud 2010;13(1):201-12.

Lester J. Work-life balance and culturela change: a narrative of eligibility. Rev High Educ 2013;36(4):463-88.

Lingard HC, Yip B, Rawlinson S, Kvan T. The experience of burnout among future construction professionals: a cross-national study. Constr Manag Econ 2007;25(4):34557.

Lockwood NR. Work/Life Balance Challenges and Solutions, SHRM Research Quarterly. USA: Society for Human Resources Management; 2003.

Mariappanadar S. Sustainable human resource strategy: the sustainable and unsustainable dilemmas of retrenchment. Int J Soc Econ 2003;30(8):906-23.

McFarlane A. Flexible working information sheets; 2009. Retrieved from 〈http://www.york.ac.uk/admin/hr/employee s/attendance_leave/info_sheets. htm〉.

Moore F. Work-life balance: contrasting managers and workers in an MNC. Empl Relat 2007;29(4):385-99.

Moore J. Homeworking and work-life balance: does it add to quality of life? Rev Eur Psychol Appl 2006; 56:5-13.

Nicolaisen $\mathrm{H}$. Changes in the regulation of overtime under different collective bargaining regimes: a comparison of Irish, Norwegian and Swedish banking. Eur J Ind Relat 2011;17(1):7-23.

Parkers LP, Langford PH. Work-life balance or work-life alignment? A test of the importance of work-life balance for employee engagement and intention to stay in organizations J Manag Organ 2008; 14:267-84.

Perrewe, P. L., Treadway, D.C., \& Hall, A.T. (2003). The work and family interface: Conflict, family friendly policies, and employee well-being. In D. A. Hoffman \& L. 
E. Tetrick (Eds), Health and safety in organizations: A multilevel perspective (pp. 285-315). San Francisco: Jossey-Bass.

Puigarnau E, Ommeren J. Start time and worker compensation: implications for staggeredhours programs. TI 2010-073/3: Tinbergen Institute Discussion Paper; 2010.

Rooney, J.A., \&Gottlieb, B.H. (2007). Development and initial validation of a measure of supportive and unsupportive managerial behaviors. Journal of Vocational Behavior, 71, 186-203.

Stella O, Paul S, Olubusayo F. Work-life balance practices in Nigeria: a comparison of three sectors. J Compet 2014;6(2):3-14.

Susi. S, J. (2010). Work-Life Balance: The key driver of employee engagement. Asian journal of management research, 1-10.

Thomas, L. T., \& Ganster, D. C. (1995). Impact of family-supportive work variables on workfamily conflict and strain: A control perspective. Journal of Applied Psychology, 80, 6-15.

Thompson, C.A., Beauvais, L.L., \& Lyness, K.S. (1999). When work-family benefits are not enough: The influence of work-family culture on benefit utilization, organizational attachment, and work family conflict. Journal of Vocational Behavior, 54, 392-415.

Ungerson C, Yeandle, S (2005). Care Workers and Work-Life Balance: The Example of Domiciliary Careworkers. In: Hounston DM, ed. Work-Life Balance in the 21st Century, pp. 246-262. Hampshire, Palgrave Macmillan.

Valcour, M. (2007), 'Work-Based Resources as Moderators of the Relationship Between Work Hours and Satisfaction with WorkFamily Balance,' Journal of Applied Psychology, 92, 6, 1512-1523.

Wayne JH, Cordeiro BL. Who is a good organizational citizen? Social perception of male and female employees who use family leave Sex Roles 2003; 49:233-46.

Wilkinson SJ. Work-life balance in the Australian and New Zealand surveying profession. Struct Surv 2008;26(2):120-30.

\section{ABOUT THE AUTHORS}

Md. Miraj Hossen, email: miraj.hossen@yahoo.com

Mr. Md. Miraj Hossen, Doctoral candidate, is a university teacher since January, 2008 and currently serving as an assistant professor in the Department of Management Studies, Jagannath University, Dhaka, Bangladesh. Now he is completing his PhD majoring in Administrative Management in Huazhong University of Science and Technology, P. R. China. He is a HRM graduate from University of Dhaka (Bangladesh). His interested research areasHRM (GHRM, IHRM, EHRM, Work-life Balance), OB \& Psychology, and Socio-economic aspect of the world. He has published a good number of scholarly articles in the national and internationally reputed journals.

Ms. Mareum Begum, Master degree student, is a civil servant of People's Republic of Bangladesh since August, 2011. In her service tenure, she has served many years in the Ministry of Health and Family Welfare and currently she is working as an Assistant Chief under the Ministry of Planning. Now she is doing her $2^{\text {nd }}$ Master degree majoring in EGovernment under the College of Public Administration, Huazhong University of Science and Technology, P. R. China. Her areas of research interests' are Public sector management, Green management, E-government, Digital governance, and Technological innovation.

Ms. Chen Zhixia, is a professor in the College of Public Administration, Huazhong University of Science and Technology, P. R. China. She has completed her gradation and master degree in Advanced Psychology and PhD majoring in Management Engineering. She is supervising many local and foreign students in PhD and Master degree program. She has experience to work as a visiting scholar in Princeton University and University of Delaware. She has published many scholarly articles in local and international journals. Her areas of research interests are- Human Resource Management, Organizational Behavior, and Applied Social Psychology \& Social Management. 